Available online at: http://ejournal-balitbang.kkp.go.id/index.php/iaj

\title{
STUDIES ON Aeromonas hydrophila BACTERIA DISEASES IN WILD AND CULTURED ELVER EEL (Anguilla bicolor)
}

\author{
Noviana Dewi*** and Isti Koesharyani*) \\ *) Fish Quarantine, Quality Control and Food Safety for Fish Products \\ ${ }^{*}$ Central for Fisheries Research
}

(Received 17 July 2017; Final revised 11 October 2017; Accepted 11 October 2017)

\begin{abstract}
This study was performed to detect Aeromonas hydrophila infection in wild and cultured elver eel (Anguilla bicolor). In total, 20 live elvers (10 wild and 10 cultured) were collected and subjected to Aeromonas hydrophila tests. Polymerase Chain Reaction (PCR) was done for an accurate identification of Aeromonas hydrophila using an universal primer and detection of the aerolysin gene in A. hydrophila using a specific primer. The virulence of $A$. hydrophila was determined using a pathogenicity test injection. The results showed that $A$. hydrophila could be detected using PCR and amplification of 685bp DNA. A. hydrophila could also be confirmed to contain the aerolysin gene of 290 bp DNA which could be a virulence indicator. Pathogenicity test revealed that $\mathrm{LC}_{50}$ was estimated to be $10.9 \times 10^{6.33}$. Histopathological changes were found in the abdominal and wounded muscles. Those changes were mainly in tissue ephitel cell hyperplasia. Based on the present study, A. hydrophila is a virulent bacteria in elver eel. A. hydrophila disease preventive measures need to be formulated. Elver eels should be tested for the A. hydrophila before restocking into farms.
\end{abstract}

\section{KEYWORDS: disease; bacteria; eel; Polymerase Chain Reaction}

\section{INTRODUCTION}

In recent years, eel (Anguilla bicolor) has shown an increase in its commercial value due to its nutritional and medicinal benefits. Eel culture has expanded considerably in Indonesia. In 2012, the world demand for eel was 14.041 tons (FAO, 2014). At present, a significant attention has been focused on the decline of wild eel stocks worldwide. For example, Japan wild eel stock was down to $64 \%$ Europe $43.5 \%$ and United State of America (USA) 8.3\%in the period of 17 years (1984-2000) (Ringuet et al., 2002).

Indonesia has now become an important source of wild eel seed for Asian countries. However, many illegal exports of glass eel from Indonesia has caused a sharp decline in wild seed population. In order to maintain a healthy wild stock population of Indonesian eel, the Ministry of Marine Affairs and Fisheries of Indonesia (MOMAF) has issued the decree

\footnotetext{
\# Correspondence: Fish Quarantine, Quality Control and Food Safety for Fish Products. JI. Enggano Raya No. 16, Tanjung Priok, Jakarta Utara, Indonesia.

Phone: + 622143910470

E-mail: priok@ bkipm.kkp.go.id;

karantinaikan.tanjungpriok@gmail.com
}

Number 19/Men/2012 (PERMEN KP No PER 19/MEN/ 2012) regarding Limitation Size of Eels for Export. This regulation stipulates that the minimum export size of eels is $150 \mathrm{~g}$ or above. The regulations also strictly prohibit the export of glass eels and elver.

The contributing factors in the decline of wild stock of eel may include overfishing, habitat loss, migration barriers, and chemical pollution, and/or a combination of these factors. Infectious diseases, however, have received little attention. In eel farming systems, diseases are lethal under certain stressful conditions and high stocking densities. Diseases are a crucial factor which limits the expansion of eel's aquaculture. A wide variety of bacterial agents have been recorded as significant problems in eel's aquaculture (McKinnon, 2006).

In Indonesia, major gaps still exist in understanding eel bacterial disease and its prevention. Therefore, research to improve our understanding of exotic diseases including eel diseases are of importance for the industry.

The aim of present study was to observe bacteria, Aeromonas hydrophila diseases infection in wild and cultured elver stage of eel, Anguilla bicolor. The 
pathogenicity of Aeromonas hydrophila infected to elver eel was also examined. Aeromonas species including Aeromonas hydrophila are becoming dangerous in recent years in fish pathology (Yogananth et al., 2009).

\section{MATERIALS AND METHODS}

\section{Elver samples}

Eighty wild live eels (elver stage) (Anguilla bicolor) with body weight ranged between $0.60-0.75$ $\mathrm{g}$ and total length ranged between 5.0-6.5 cm were collected during February 4-16, 2015 at Cimandiri River, Pelabuhan Ratu, Sukabumi District. In addition, sixty cultured eels (elver stage) with body weight ranged between $0.62-0.71 \mathrm{~g}$ and total length ranged between 5.1-6.4 cm were collected from the Laboratory of The Department of Management Water Resources, Bogor Agriculture University (IPB).Ten of each wild and cultured elver were used for Aeromonas hydrophila bacterial examination.

\section{Bacterial identification}

Bacteria were isolated from wounded skins and intestines of the elver. Primary isolation was carried out by taking with a loop from different organs of the elver including intestine and wounded muscles. In order to identify Aeromonas hydrophila bacteria, the samples were cultured on Tryptone Soya Agar (TSA) plates at $28^{\circ} \mathrm{C}$ for 24 hours for phenotypic and genotypic identifications (Gardenia et al., 2010)

Bacterial Aeromonas hydrophila isolates from a single colony on TSA was tested using Gram-staining, catalase and oxidase tests. Strains, which had positive catalase and Gram-negative rods, were subcultured on TSA and incubated overnight to get pure colonies. Purified bacterial cells were then inoculated into TSB for PCR assay. Aeromonas hydrophila AH-26, an isolate belongs to the Center for Fisheries Research, Jakarta, was used as a reference isolate.

\section{Identification using PCR assay}

DNA was extracted from three isolates. Bacteria pellets were made by centrifuging the isolates in a microtube at $1200 \mathrm{xg}$ for $10 \mathrm{~min}$. The pellets were resuspended with $400 \mathrm{uL}$ RNAse water-free and heated at a temperature of $98{ }^{\circ} \mathrm{C}$ for $10 \mathrm{~min}$, and occasionally vortexed. The microtubes were then dipped in ice for 1-2 min and then vortexed again. The bacteria DNA were centrifuge at $800 \mathrm{xg}$ for $10 \mathrm{~min}$ and $300 \mathrm{uL}$ of the supernatant containing DNA were collected to a new microtube and kept in a freezer at $-20^{\circ} \mathrm{C}$ for further use. DNA extraction was first evaluated by the amplification of the 16S rRNA gene using the gene sequence of the universal primers shown in Table 1. The procedures for thermocycler followed Gardenia et al. (2010). PCR products were visualized by gel staining on $1.5 \%$ agarose gel electrophoresis.

\section{Pathogenicity test}

The bacteria strain of $A$. hydrophila isolated from elver samples was used in the pathogenicity test. The bacteria were grown on tryptic soy broth (TSB, Difco) for $24 \mathrm{~h}$ at $30^{\circ} \mathrm{C}$ then broth cultures were centrifuged at $7000 \mathrm{rpm}$ for $15 \mathrm{~min}$ at $4^{\circ} \mathrm{C}$ and the bacterial pellets were washed twice with sterile phosphate buffered saline (PBS; pH 7.4) via centrifuging at 14.000 rpm for 1 min. The pellet was re-suspended in PBS and adjusted to $1 \times 10^{8} \mathrm{cfu} / \mathrm{mL}$. Afterward the concentration of $10^{6}, 10^{7}$, and $10^{8} \mathrm{cfu}$ of bacteria were prepared in $30 \mu \mathrm{L}$ solution for pathogenicity test. The bacterial concentration was estimated through optical density using a spectrophotometer. The experimental elvers were injected with the A.hydrophila suspension. The mean $\mathrm{LC}_{50}$ and total mortality were measured. The result of pathogenicity test was estimated according to Dragest Behrens (Hubert, 1980) as follow;

$$
M=x 1+d / \%+1-\% x 1
$$

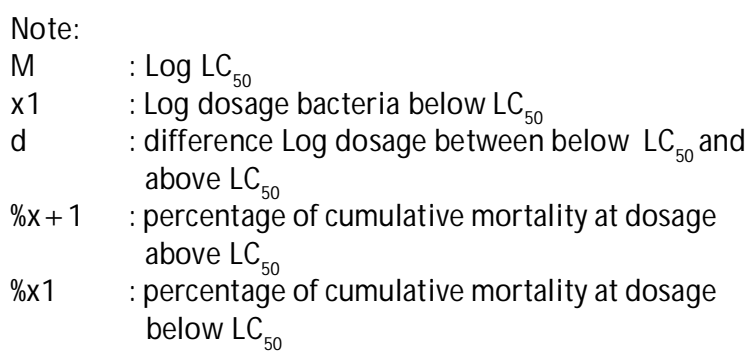

The pathogenicity of $A$. hydrophila is caused by exotoxins such as aerolysin (Shome et al., 2005). Polymerase chain reaction was used to detect 209 bp gene of aerolysin in the isolates. Specific primers for the aerolysin gene are presented in Table 2 .

\section{Histology}

Tissue samples from moribund and infected elver were collected for histological studies. Muscle tissues of moribund elver were fixed in Davidson's solution (Pandey et al., 2010). The fixed specimens were embedded in paraffin and cut into $5 \mu \mathrm{m}$ sections, stained with Gram stain and with modified Mayer's hematoxylin and eosin stain before being observed under a light microscope. 
Table 1. Universal primer sequences used for PCR assay for Aeromonas hydrophila (Dorsch et al., 1994)

\begin{tabular}{llcc}
\hline Primer pair universal & \multicolumn{1}{c}{ Sequence (5'3') } & Position & Molecul weight \\
\hline 165 rDNA-1 & 5'-GAAAGGTTGATGCCTAATACGTA-3' & $451-473$ & \multirow{2}{*}{$685 \mathrm{bp}$} \\
16S rDNA-2 & 5'-CGTGTGGCAACAAAGGACAG-3' & $1,115-11,135$ & \\
\hline
\end{tabular}

Table 2. Specific primer sequences used for PCR assay for aerolysin gene (Pollard et al., 1990)

\begin{tabular}{|c|c|c|c|}
\hline Primer pair specific & Sequence (5'3') & Position & Molecul weight \\
\hline AeroFD & 5'-CCAAGGGGTCTGTGGCGACA-3' & $645-664$ & \multirow{2}{*}{$209 \mathrm{bp}$} \\
\hline AeroRs & 5'-TTTCACCGGTAACAGGATTG-3' & $834-853$ & \\
\hline
\end{tabular}

\section{RESULTS AND DISCUSSION}

In total, 20 eel elver samples (10 wild and 10 cultured) were collected and subjected to clinical sign and bacteriological examinations. In this study, both samples of wild and cultured elver for Aeromonas hydrophila produced yellow colonies in the Tryptone Soy Agar (TSA) soy. Gram staining of these colonies gives a gram-negative reaction. Microscopic analysis gives rod-shaped and motile biochemical tests gives oxidase positive (Table 3).

Polymerase chain reaction (PCR) was used to detect 685 bp gene in the isolates. Based on PCR analysis, all isolates from wild and cultured elver were confirmed to be the species of Aeromonas hydrophila (Figure 1).

These pathogens are mesophilic motile and psychrophilic nonmotile gram-negative ubiquitous bacteria (Kingombe et al., 1999) and cause gastroenteritis, septicemia, and diarrhea in humans and hemorrhagic septicemia in fish (Altwegg, 1999). Buckley et al. (1999) mentioned that increased incidence of diseases in fish, man and animals may caused by Aeromonas sp. including Aeromonas hydrophila. Aeromonas hydrophila is a ubiquitous and heterogeneous organism and can be associated with wound infections.

Aeromonas spp. are found worldwide in aquatic environments, including ground, surface, estuarine and marine, drinking, and waste water. They are also found in foods, including fresh grocery products, seafood, raw meats, packaged ready-to-eat meats, cheese, and milk. Aeromonas hydrophila has been recognized as bacterial pathogen since they were first isolated from diseased fish. They are now recognized to cause disease in many fish species including eel and shellfish species (Yousr et al., 2007; Sharma et al., 2009).

Most of the elver injected with a high dose of bacteria $\left(10^{7}-10^{8} \mathrm{cfu} / \mathrm{ml}\right)$ started to die within 2 days. Pollard et al. (1990) reported the development of a PCR procedure for rapidly and specifically detecting aerolysin genes in strains of hemolytic oligonucle-

Table 3. Phenotypic characteristics of Aeromonas hydrophila isolated from elver for both wild and cultured elver compared to standard strain A. hydrophila (Kingombe et al., 1999)

\begin{tabular}{lcc}
\hline \multicolumn{1}{c}{ Test items } & Isolate A. hydrophila & A. hydrophila standard \\
\hline Color of colony & Yellow & Yellow \\
Gram staining & - & - \\
Cell morphology shape & Rod & Rod \\
Catalace & + & + \\
Oxidase & + & + \\
\hline
\end{tabular}




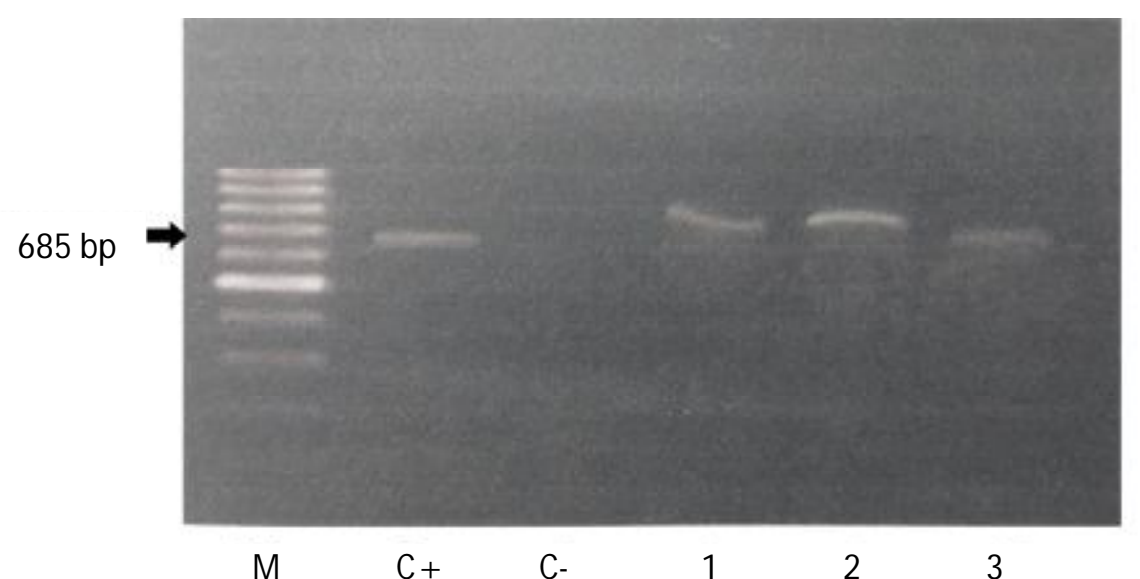

Figure 1. Detection of Aeromonas hydrophila.using PCR and amplification of 685 bp DNA bands visualized on $2 \%$ agarose gel. M: Indicates the 100 bp ladder. +C Positive control, -C: Negative control, No 1,2 and 3 are isolated A hydrophila.

otide primers. These primers targeted a 209-bp fragment of Aer gene coding for hemolytic and detecting template DNA only in PCR. In the present study, PCR amplification of DNA from pathogenic $A$. hydrophila isolates using specific primers for hemolysin genes resulted in the expected PCR products of 209 bp size in lane number three (Ae). The present study confirms that $A$. hydrophila has a virulence gene named aerolysin (Figure 2). Re-isolation of A. hydrophila from apparently healthy elvers confirmed the pathogenic effect of this isolate to the injected elver.

In the experimental challenge test, a mortality of $50 \%\left(\mathrm{LC}_{50}\right)$ occurred in the elvers that were injected with $30 \mu \mathrm{L}$ PBS containing A. Hydrophila at $10^{6} \mathrm{cfu}$ and $100 \%$ mortality in elvers injected with $10^{8} \mathrm{cfu}$ of A. hydrophila concentration. Estimation of $\mathrm{LC}_{50}$ is $10.9 \times 10^{6.33} \mathrm{cfu} / \mathrm{mL}$ which was calculated by the formula of Huberrt (1980). No mortality occurred in the control group (Figure 3).

The pathogenicity and virulence characteristics of A. hydrophila are associated with the presence of different exotoxins e.g., cytotoxins and exoenzymes (Walker, 1997). The two major groups of hemolysins such as extracellular hemolysin and aerolysin are produced by A. Hydrophila (Kozaki et al., 1989.). Histopathological changes in the elvers were found in

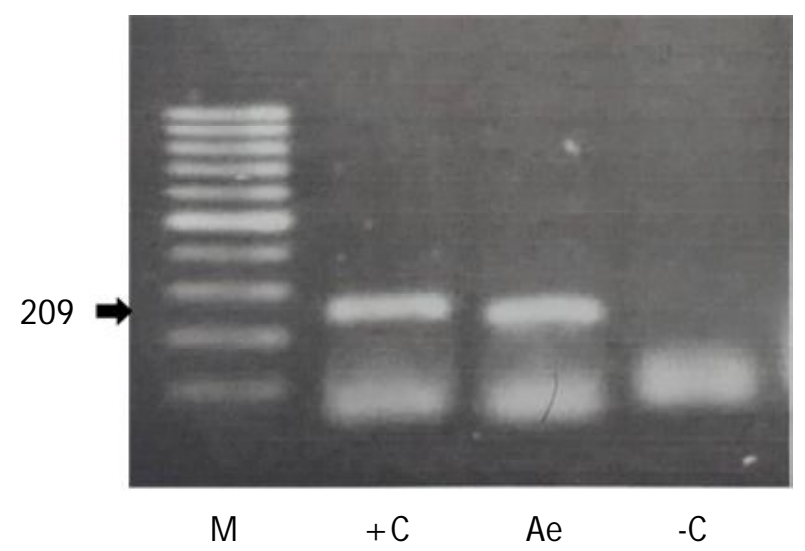

Figure 2. Detection of aerolysin in Aeromonas hydrophila-infected elvers using PCR and amplification of 209bp DNA bands visualized on $2 \%$ agarose gel. $\mathrm{M}$ : Indicates the 100 bp ladder. $+\mathrm{C}$ : Positive control aerolysin, Ae: Aerolysine in infected elver $-\mathrm{C}$ : Negative control. 


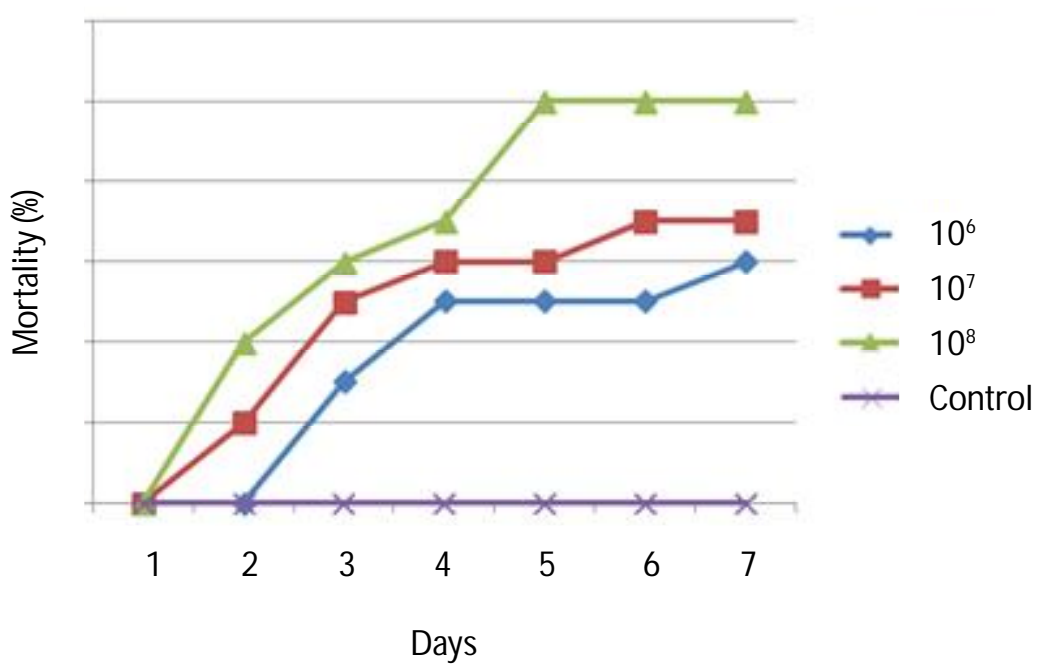

Figure 3. Mortality rate of elver intramuscularly injected with various concentration of Aeromonas hydrophila.

abdomen muscle. Most of the muscular tissues had been damaged (Figure 4).

A. hydrophila is responsible for causing Motile Aeromonas Septicemia (MAS), Hemorrhagic Septicemia, Ulcer disease or Red-Sore disease in freshwater fishes. Stress is the main underlying factor in A. hydrophila infection in addition to mishandling, overcrowding, transportation under poor conditions, poor level of nutrition and poor water quality. A. hydrophila is the most common representative of Aeromonas found in water, domestic animals and foods (fish, shellfish, poultry, and raw meat). The microorganism has the potential to be a foodborne pathogen (Sharma et al., 2009).

Infectious diseases, in general, should be considered as possible serious factors in the decline of the wild and cultured eel stocks. In Indonesia, the combination of A. hydrophila bacteria and migration stress up to rivers has increased the chance of the disease infection. Therefore, health assessment of elvers should be conducted on a regular basis in Indonesia. Disease preventive measures need to be formulated and assessed, resulting in strict and detailed international legal measures. Farmed eels should be tested for A. hydrophila diseases before restocking into the farm. Quarantine and diseases examinations using proper methods should be applied when importing eels from other sites.

\section{CONCLUSION}

The bacteria infecting both wild and cultured wild elver eels was identified as Aeromonas hydrophila. It is a pathogenic bacteria with pathogenicity $\left(\mathrm{LC}_{50}\right)$ of
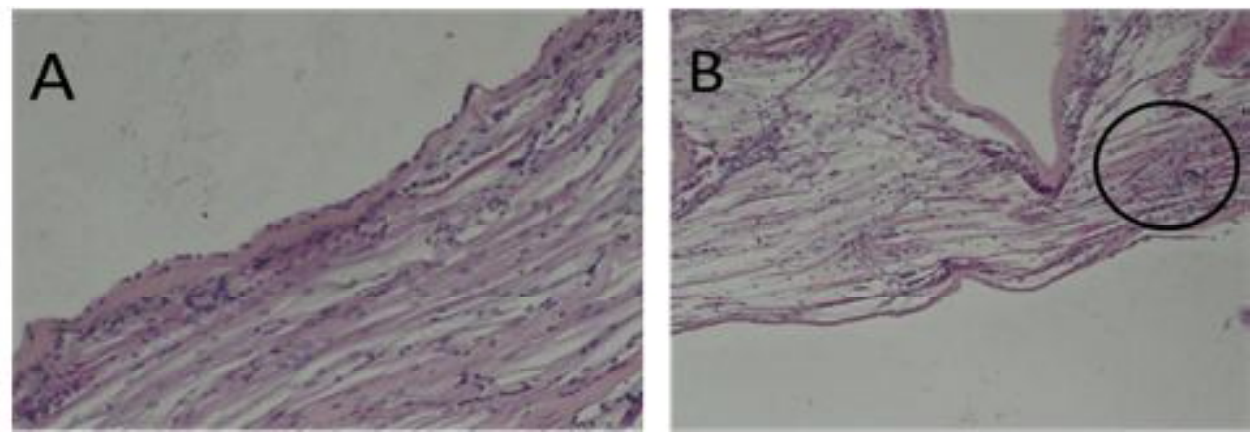

Figure 4. A histopathology of healthy elver muscle (A) and epithelial cell hyperplasia in muscle of infected elver (B) (400x). 
$10.9 \times 10^{6.33}$. This bacteria has aerolysin gene which could be used as an indicator of virulence.

\section{ACKNOWLEDGMENT}

The authors thank the Department of Management Water Resources. Bogor Agriculture University (IPB) for providing necessary facilities. The author also acknowledges to BKIPM Jakarta for assisting in providing laboratory equipments during conducting the present study.

\section{REFERENCES}

Altwegg, M. (1999). Aeromonas and plesiomonas. In Murray, P.R., Baron, E.J., Pfaller, M.A., Tenover, F.C., $\&$ Yolken, R.H. (Eds.), Manual of Clinical Microbiology. Washington D.C.: American Society for Microbiology, p. 507-516.

Buckley, J.T. \& Howard, S.P. (1999), The cytotoxic entero-toxin Aeromonas hydrophila is aerolysin. Infection and Immunity, 67(1), 466-467.

Dorsch, M., Asbolt, N.J., Cox, P.T., \& Gooodman, A.E. (1994). Rapid identiication of Aeromonas species using 16S rDNA targeted oligonucleotidde primers: a molecular approach based on screening of enviromental isolates. J. of Applied Biotechnology, 77, 722-726.

Food and Agricultural Organization [FAO]. (2012). Fishery and aquaculture statistics. Year Book, Annual A1 \& A6.

Gardenia, L., Koesharyani, I., \& Mufidah, H. (2010). Aplikasi deteksi Aeromonas hydrophila penghasil Aerolysin dengan menggunakan PolimeraseChain Reaction (PCR). Forum Inovasi Teknologi Akuakultur. Pusat Riset Perikanan Budidaya. Jakarta, hIm. 877883.

Hubert, J.J. (1980). Bioassay. St Louis, Toronto, London: Kendall Hund Publishing Company, p. 101104.

Kingombe, C.I.B., Huys, G., Tonolla, M., Albert, M.J., Swings, J., Peduzzi, R., \& Jemmi, T. (1999). PCR detection, characterization and distribution of virulence genes in Aeromonas spp. Applied \& Environmental Microbiology, 65(12), 5293-5302.
Kozaki, S.A., Tsutomu, K., Yoichi, \& Sakaguchi, G. (1989). Characterization of Aeromonas sobria Hemolysin by use of monoclonal antibodies against Aeromonas hydrophila Hemolysins. Journal of Clinical Microbiology, 27(8), 1782-1786.

McKinnon, L.J. (2006). A review of eel biology: Knowledge and gaps. Report to EPA Victoria, $39 \mathrm{pp}$.

Pandey, A., Naik, M., \& Dubey, S.K. (2010). Hemolysin, protease, and EPS producing pathogenic Aeromonas hydrophila strain An4 shows antibacterial activity against marine bacterial fish pathogens. Journal of the Marine Biology, 20, 2-11.

Pollard, D.R., Johson, W.M., Lior, H., Tyler, D., \& Rozee, K.R. (1990). Detection of aerolysin gene in Aeromonas hydrophila, by the polymerase chain reaction. J. of Clinical Microbiology, 28(11), 2477-2481.

Ringuet, S., Muto, F., \& Raymakers, C. (2002). Eel: Their harvest and trade in Europe and Asia. Traffic Bulletin, 19(2), 27 pp.

Sharma, I,, Kumar, A., \& Pramanik, A.K. (2009). Review of techniques on isolation and identification of Aeromonads from the food of animal and fish origin. Assam University Journal of Science \& Technology: Biological Sciences, 4(1), 73-85.

Shome, R., Shome, B.R., Mazumder, Y., Das, A., Kumar, A., Rahman, H., \& Bujarbaruah, K.M. (2005). Abdominal dropsy disease in major carps of meghalaya: isolation and characterization of Aeromonas hydrophila. Current Science, 88(12), 18971900.

Yogananth, N., Bhakyaraj, R., Chanthuru, A., Anbalagan, T., \& Mullai, K.N. (2009). Detection of virulence gene in Aeromonas hydrophila isolated from fish samples using PCR technique. Journal of Plant Biochemistry and Biotechnology, 4(1), 51-53.

Yousr, A.H., Napis, S., Rusul, G.R.A., \& Son, R. (2007). Detection of aerolysin and hemolysin genes in Aeromonas spp. isolated from environmental and shellfish sources by polymerase chain reaction. ASEAN Food Journal, 14(2), 115-122.

Walker, S.J. (1997). Survey of the incidence of Aeromonas and Yersinia species in retail foods. Food Control, 4(1)1, 34-40. 